\title{
EL ORDEN SEÑORIAL Y SU REPRESENTACIÓN SIMBÓLICA: RITUALIDAD Y CEREMONIA EN CASTILLA A FINES DE LA EDAD MEDIA
}

\author{
$\mathrm{M}^{\mathrm{a}}$ CONCEPCIÓN QUiNTANILla RASO \\ Universidad Complutense de Madrid
}

\begin{abstract}
SUMARIO
I.Introducción: Orden señorial y representación.- II. Estructura y significado de las ceremonias: 1. Formas legitimadoras de acceso al señorío. 2. Presencia de protagonistas. 3. Escenario.- III. La puesta en escena: Formalismo y simbolismo: 1. Actitudes y gestos señoriales. 2. La gestualidad vasallática.- IV. Conclusión: Imágenes y mensajes.
\end{abstract}

\section{INTRODUCCIÓN. \\ ORDEN SEÑORIAL Y REPRESENTACIÓN}

La dimensión señorial constituía en la baja Edad Media el elemento vertebral del rango de alta nobleza, identificado claramente con su condición de señores de villas y vasallos; así se reconocía en el tratamiento -como "muy ilustre señor don", o "muy magnífico señor don"-, que, junto a otros elementos configuraba lo que se ha dado en denominar la imagen nominal 
del individuo noble ${ }^{1}$. Por otra parte, los numerosos señoríos acumulados, e integrados en grandes estados señoriales se convirtieron en una de las fórmulas más eficaces y manifiestas del proceso de consolidación y renovación de la nobleza tardomedieval ${ }^{2}$.

El señorío constituía un marco de estrechas y complejas relaciones, de poder-mandato, y obediencia-sumisión, en torno al cual se generaron expresivas imágenes simbólicas. Resulta evidente que el orden señorial no alcanza su verdadera entidad, si no se aborda desde la perspectiva de un sistema de relaciones en las que se integran los dos elementos constituyentes. En su dimensión real, la proyección del poder señorial se plantea siempre en términos de legitimación, declaración, imposición, pero también de aceptación, y, en relación con este último aspecto, toda instancia de poder necesita, para su ejercicio y puesta en práctica, de un sistema de representación, orientado a justificar y hacer más perceptibles sus capacidades, y, al mismo tiempo, a diseñar una opinión de aceptación, o conformidad, respecto de sus intereses y pretensiones. Como afirma Balandier, un poder establecido sólo por la fuerza o violencia estaría constantemente amenazado, mientras si sólo estuviera basado en la razón, carecería de entidad y credibilidad; por el contrario, el objetivo de todo poder es mantenerse, mediante un adecuado sistema de representación, que, trascendiendo la realidad inmediata, aparece incardinado profundamente en ella, orientado a sintetizarla, y, en definitiva, a reafirmarla y completarla ${ }^{3}$.

'Faustino MENÉNDEZ PIDAL, Los emblemas heráldicos. Una interpretación histórica, Real Academia de la Historia, Madrid, 1993, p. 59, donde alude a los elementos y precisiones que fueron añadiéndose al sistema de denominación, para perfeccionarlo y ampliar su proyección social.

${ }^{2}$ Sobre la articulación y estructura de los amplios conjuntos de villas señoriales nobiliarias, ver Isabel BECEIRO PITA, Los estados señoriales como estructura de poder en la Castilla del siglo XV, en "Realidad e imágenes del poder. España a fines de la Edad Media”, A. Rucquoi, coord., Valladolid, 1988, pp. 293-323. Para una aproximación bibliográfica a la nobleza castellano-leonesa en dicho período: $\mathrm{M}^{\mathrm{a}}$ Concepción QUINTANILLA RASO, El protagonismo nobiliario en la Castilla bajomedieval. Una revisión historiográfica (1984-1997), en "Medievalismo", 7 (1997), pp. 187-233. En cuanto al proceso de renovación nobiliaria bajomedieval, he expuesto un conjunto de reflexiones en mi artículo titulado: La renovación nobiliaria en la Castilla bajomedieval. Entre el debate y la propuesta, en "La Nobleza Peninsular en la Edad Media". VI Congreso de Estudios Medievales. Fundación SánchezAlbornoz, León, 1999, pp. 255-296.

${ }^{3}$ Georges BALANDIER, El poder en escenas. De la representación del poder al poder de la representación, Barcelona, 1994. Desde una perspectiva de Antropología política, el autor insiste en la necesidad de la utilización de símbolos, escenario, rituales, demostraciones públicas, y, en definitiva, de una verdadera dramaturgia, orientada hacia la demostración o exhibición del poder, como algo consustancial al mismo. Interesantes consideraciones acerca 
La configuración del poder nobiliario se basaba en una táctica de legitimación, -tanto en la dimensión que podemos denominar esencial, como en la concreta y circunstancial-, y, al mismo tiempo, en su publicitación y propaganda ${ }^{4}$. En la perspectiva legitimadora, la potestas señorial se inscribía, en el período bajomedieval, en un marco de relaciones noblezamonarquía, en el que la primera alcanzó a obtener una capacidad de ejercicio del poder que partía del sentido de delegación, hasta plantearlo, en una tendencia generalizada, sobre la base de la auto-consideración como potestad propia y directa. Las claves de la legitimación profunda de las capacidades señoriales nobiliarias formaban parte del proceso general de justificación de los aspectos de preeminencia y de dominación de la nobleza sobre el conjunto social. A lo largo de una larga evolución, el titular del señorío bajomedieval habia conseguido acumular atribuciones, derechos, y -al mismo tiempo-, responsabilidades que se traducían en una amplísima capacidad de mandato, y posibilidades de exacción fiscal, como compensación por el ejercicio de todas esas funciones. La gracia regia, y la voluntad nobiliaria, se convirtieron en los elementos básicos de una autoridad señorial justificada, en el plano concreto, por el título de adquisición, -donación regia, sucesión, compra, traspaso-.

Con todo, el poder señoríal debía ser explicitado ante los destinatarios, y acatado por ellos, para lograr su verdadera y completa configuración. En relación con esto último, resultaba determinante el hecho del acceso al señorío, a cuyo efecto era preceptiva la puesta en práctica de un acto, dotado de un rico simbolismo, que, si por un lado se presentaba como una toma de posesión, por parte del señor, para los otros protagonistas tenía el sentido de entrega del mismo. Se trataba de una ceremonia que proyectaba una imagen codificada, completa y estructurada del poder señorial, y de la obediencia vasallática, a través de un lenguaje diversificado, que no sólo exhibía, sino

del concepto de representación, aunque aplicado a la monarquía, en el artículo de José Manuel NieTo SoRIa Propaganda política y poder real en la Castilla Trastámara: Una perspectiva de análisis, "Anuario de Estudios Medievales", 25/2, (1995), pp. 490-515. Recientemente ha insistido en el aspecto de la representación como necesidad a propósito de la actividad propagandística de la dinastía Trastámara, en La sociedad política. La Realeza, en “Orígenes de la Monarquía Hispánica. Propaganda y legitimación (circa 1400-1520)”, Madrid, 1998, pp. 25-62.

${ }^{4}$ Un tratamiento pormenorizado de estas cuestiones, desde perspectivas teórico-metodológicas, y a la vez, una aproximación a la realidad, en un reciente trabajo: $M^{a}$ Concepción Quintanilla Raso, La sociedad políica. La Nobleza, en "Orígenes de la Monarquía Hispánica....", ob. cit. pp. 63-103. 
que hacía a señores y vasallos. Dichos actos se convirtieron en un eficaz sistema de comunicación de las competencias señoriales, y de los compromisos vasalláticos, mediante una puesta en escena, en un contexto ceremonial, a través del cual se generaban imágenes y mensajes recíprocos, y se producían los efectos oportunos, que afectaban directamente a emisores y receptores, las instancias implicadas.

De entre todos los registros a utilizar para el estudio del orden señorial, destaca la conveniencia de adentrarse en la representación simbólica plasmada en las ceremonias de acceso al señorío. Este tipo de representación figurada de los hechos constituye un aspecto del máximo interés para el conocimiento de la sociedad que los vivía, y está ya más que demostrada la conveniencia del conocimiento del aparato conceptual aceptado por individuos y colectividades, y puesto en práctica en sus pensamientos y en sus actuaciones ${ }^{5}$. Hace más de veinte años, Jacques Le Goff llamaba la atención sobre el hecho de que la sociedad medieval reforzó la dimensión simbólica -inherente, por otra parte, a toda sociedad-, por la aplicación de un sistema ideológico de interpretación simbólica a la mayoría de sus actividades y relaciones, haciendo notar la importancia del simbolismo en los ritos del vasallaje ${ }^{6}$.

Tales ceremonias de toma de posesión, de las que existen suficientes testimonios documentales para el ámbito castellano-leonés, en especial referidas al siglo $\mathrm{XV}$, no empezaron a ser objeto de atención en toda su entidad hasta la década de los ochenta; hasta ese momento, parecían interesar sólo para constatar que la toma de posesión se había producido, superponién-

\footnotetext{
${ }^{5}$ Ver las consideraciones respecto a la compleja problemática del ámbito ideológico y mental, ofrecidas por Michel VOVELLE, Ideologías y mentalidades, Barcelona, 1985, especialmente en su Introducción, pp. 7-19, donde analiza la entidad y contenido, tanto del plano ideológico, como de la perspectiva mental, situando esta última como inscrita en el concepto más amplio de ideología, y atribuyéndole un contenido relacionado con los gestos, actitudes, y representaciones colectivas, que representaban el estrato intermedio de relación entre las condiciones objetivas de la vida, y la manera en que los individuos la cuentan y la viven. En una perspectiva más próxima, el artículo de José Manuel NiETo SoRIA, Ideología y centralización política en la crisis bajomedieval: vías de aproximación y dificultades interpretativas, "Historia a Debate. Medieval", C. Barros, edit., Santiago de Compostela, 1995, pp. $151-161$.

${ }^{6} \mathrm{Me}$ refiero a su extenso e interesante texto sobre Les gestes symboliques dans la vie sociale. Les gestes de la vassalité, en "Settimane di Studio del Centro Italiano di studi sull'alto Medioevo", XXIII, abril de 1975, dedicado a "Simboli e simbologia nell "alto Medioevo", editado en Spoleto, 1976, II, pp. 679-788, que luego se ha difundido, sobre todo, en su versión posterior, en castellano: El ritual simbólico del vasallaje, en "Tiempo, trabajo y cultura en el Occidente Medieval”, Madrid, 1983, pp. 328-394.
} 
dose a cualquier posible recelo o incluso resistencia de la población, una circunstancia relativamente frecuente, por otra parte. Más tarde, el tipo documental en sí, y su contenido, fueron rescatados por una historiografía que intentaba fundamentar el conocimiento de la realidad señorial sobre bases más firmes, y a partir de enfoques diversos y complementarios ${ }^{7}$.

El tipo diplomático específico, dentro del esquema de la documentación señorial, pertenece al grupo de los documentos notariales, dentro de los cuales se integra, a su vez, entre los narrativos, que, como tales, recogen con detalle estos actos, donde la ritualidad -en su dimensión más profunda-, y la exteriorización ceremonial -en el plano de la exhibición más caracterizada-, estaban presentes ${ }^{8}$. Durante los actos tenían cabida, en términos generales, todos los elementos simbólicos por excelencia: un escenario cargado de significado, unas palabras sencillas, pero explícitas, unos signos y objetos con doble dimensión, práctica y ritualizada, y un

\footnotetext{
${ }^{7}$ Uno de los primeros trabajos en esta línea fue el breve artículo de Isabel BECEIRO PITA. La imagen del poder feudal en las tomas de posesión bajomedievales castellanas. "Studia Historica. Historia Medieval”, 2 (1984), pp. 157-162; años después ha ampliado sus consideraciones al respecto, en otro artículo: "El escrito, la palabra y el gesto en las tomas de posesión señoriales, "Studia Historica. Historia Medieval" 12 (1994), pp. 53-82. Otros especialistas en el período bajomedieval castellano se han ocupado del tema en publicaciones específicas, como la de Miguel RODRíguEZ LLOPIS, Las tomas de posesión bajomedievales y la ideología feudal. La incorporación de la tierra de Alarcón al marquesado de Villena, "Congreso de Historia del Señorío de Villena". Albacete, 1987, pp. 349-356; o, bien, se han aproximado a la cuestión, en el contexto de estudios más generales, como los de Alfonso Franco Silva, Gandul y Marchenilla. Un enclave señorial de los Velasco en la Campiña de Sevilla, "Actas del V Coloquio Internacional de Historia Medieval de Andalucía", Córdoba, 1988, pp. 405-419. Personalmente, he mostrado mi interés en el asunto, en diversas publicaciones: $\mathrm{M}^{\mathrm{a}}$ Concepción Quintanilla Raso, Cañete de las Torres en la Baja Edad Media, en "Cañete de las Torres, Visión histórica de un pueblo andaluz", Córdoba, 1987, donde aparece publicada una interesante toma de posesión de esta villa señorial, fechada en 1424, pp. 102-106; también tuve ocasión de realizar un análisis detallado de otra situación similar, pero a través de un texto dotado de aspectos singulares, como luego se verá, en Contenidos, símbolos e imágenes del poder nobiliario en la Montilla bajomedieval, "VI Congreso de Profesores Investigadores", Córdoba, 1988, pp. 11-17; más recientemente, he vuelto a ocuparme de estos aspectos en un artículo titulado Propiedades y derechos en los señorios nobiliarios cordobeses de la Baja Edad Media. Nuevas interpretaciones, "Historia Instituciones Documentos" 24 (1997), pp. 391-414.

${ }^{8}$ Una clasificación muy completa de la documentación nobiliaria, en la obra de $\mathrm{M}^{\mathrm{a}}$ Luisa PARDO RODRíguez, Documentación del condado de Medinaceli (1368-1454). Soria. 1993. Estudio Introductorio, donde las referencias concretas a estos documentos ocupan las páginas 111-121, y, más concretamente, pp. 115-116. en las que aparecen clasificados, a su vez, en grupos distintos, de acuerdo con el carácter del relato, simple, o pormenorizado. Observaciones de interés acerca de los elementos de relación y de diferenciación entre rito y ceremonia, en Nilda GUGLIELMI, El discurso político en la ciudad mediev'al italiana (siglos XIV y XV), en "El discurso político en la Edad Media”, N. Guglielmi y A. Rucquoi, edits., Argentina, 1995, pp. 51-75, concretamente, 64-65.
} 
lenguaje gestual dotado de fuerte expresividad, conformando todo ello un verdadero sistema simbólico, en el que el conjunto de elementos respondía a una sucesión, no sólo temporal, sino lógica, y cuyo sentido se alcanzaba gracias a la integración de cada uno de los ingredientes, en un conjunto coherente.

\section{ESTRUCTURA Y SIGNIFICADO DE LAS CEREMONIAS}

Las circunstancias a partir de las cuales se desarrollaban las tomas de posesión de los señoríos, junto a unas innegables pautas generales, planteaban diferencias, que conviene tener en cuenta. En primer término, existían varias fórmulas de acceso: desde la concesión por el monarca, hasta la vía hereditaria, o la adquisición onerosa, sin olvidar el traspaso o renuncia en favor de otro, procedimiento menos frecuente, pero bien documentado; de otro lado, si bien es característica la presencia del señor en el acto de entrada y acceso al señorío, era también muy común la delegación en un individuo de su entorno próximo, que actuaba en su nombre; en lo correspondiente al espacio, existen testimonios de localizaciones distintas, dentro de la villa, pero, sobre todo, abundan las ceremonias caracterizadas por otorgar una importancia determinante, $-\mathrm{y}$ a veces hasta exclusiva - , al castillo señorial; por lo que se refiere al despliegue gestual - uno de los aspectos más característicos e interesantes-, alcanzaba un grado diverso, más o menos desarrollado, según los casos; y, en definitiva, tal vez en relación con lo anterior, o por circunstancias no bien determinadas, - la mayor o menor envergadura del señorío, o el nivel de preeminencia del titular, etc.-, el grado de expresividad logrado en la proyección de las imágenes del poder señorial, y de la correspondiente sumisión vasallática, presentaba matices diferentes, en unos y otros casos. En función de todo ello, el presente trabajo intenta ofrecer, a partir del análisis de diversos testimonios históricos, una panorámica coherente y sistematizada, en la que se pueden observar, tanto las pautas generales, como los aspectos particulares de mayor interés.

\section{Fórmulas legitimadoras de acceso al señorio}

La donación regia representaba uno de los procedimientos más habituales de acceder al señorío de una villa o lugar. El caso nos sitúa de lleno en la dimensión de la legitimación de la figura señorial, antes apuntada, 
en función de la voluntas regis, como consecuencia del entramado de relaciones socio-políticas, que aunaban estrechamente ambas instancias de poder: realeza y nobleza ${ }^{9}$. La decisión monárquica se plasmaba en un texto, que solía incluir la fórmula de la relación vinculante de servicio-gracia: "a vos....por los muchos, buenos, e leales serviçios...fago vos merçed, e graçia e donaçión buena, e pura, e perfecta, acabada, para sienpre jamás....de todo qualquier señorío e otro qualquier derecho que a mí pertenesçiere en la villa de..." ${ }^{10}$. En realidad, se trataba de un traspaso de competencias, de la realeza a la nobleza, que, en ocasiones implicaba un acto simbólico de entrega, mediante una fórmula situada en la más clara línea de la traditio chartae, como se indica en el siguiente ejemplo, referido a la concesión de la villa de Moya a don Juan Pacheco, en 1448: "E por esta mi charta, e con ella, e por la tradiçión que de ella vos fago, la qual vos do e entrego por posesión e en nonbre de posesión" ". El propio texto de la donación ya indicaba la entidad de lo concedido, y diseñaba los pasos a seguir en las ceremonias, encaminadas a lograr, textualmente, la "tenençia e posesión real, corporal, abtual, e çevill, e natural de la dicha villa e su tierra, con todo lo susodicho, e la propiedad e señorío de todo ello, e de cada cosa e parte dello", a lo que se añadía la facultad para "la entrar e tomar e vos apoderar de ella", implicando además a los otros protagonistas, el concejo y los vecinos, a quienes se dirigía expresamente el mandato regio, orientado a lograr su buena disposición en los actos encaminados al acatamiento y recepción del señor ${ }^{12}$.

En cuanto a los otros procedimientos, dependían de forma directa de la voluntad nobiliaria. El sistema hereditario de acceso estaba absolutamente

\footnotetext{
'Ver, al respecto, el artículo de Ignacio ATIENZA HERNÁNDEZ, El poder real en el siglo XV: lectura crítica de los documentos de donación de villas y lugares, "Revista Internacional de Sociología”, 47 (1983), pp. 557-591.

${ }^{10}$ Por citar un ejemplo concreto, esta fórmula se encuentra aplicada en un documento de donación del señorío de la villa de Fuensalida, por Enrique IV, el 5 de junio de 1471, a don Pedro López de Ayala, alcalde mayor de la ciudad de Toledo, y miembro del Consejo Real: cifr. Alfonso Franco Silva, El condado de Fuensalida en la Baja Edad Media. Cádiz. 1994. pp. 165-170.

"El documento se conserva en el nuevo Archivo Nobiliario, localizado en el Hospital Tavera, en Toledo: Archivo Histórico Nacional, Nobleza, Frias, caja 4, $n^{\circ} 16$, fechado en Aranda, el 25 de septiembre de 1448, que contiene la concesión de la villa por el príncipe don Enrique a Pacheco. Transcrito en la obra "Orígenes de la Monarquia Hispánica", ob. cit., doc. 61, pp. 494-495.

'Ibidem.
} 
generalizado, por razones directamente relacionadas con la propia entidad de donación, que se extendía al beneficiario y a sus sucesores, y con la consolidación de la estructura de linaje en el período bajomedieval. Esta circunstancia se convertía en fórmula habitual de legitimación para el heredero, que, en el inicio de la ceremonia, debía argumentar su situación, como se lee en la toma de posesión de la villa de Montemayor, en 25 de mayo de 1459: "por quanto el dicho Alfón de Montemayor, su señor e padre era pasado desta presente vida, por su finamiento, el dicho Martín Alfón, asy como su fijo mayor legítimo, avía quedado e era señor, e a quien pertenesçía e pertenesçe por título de mayoradgo la dicha villa de Montemayor.... esto por virtud del testamento quel dicho Alfonso de Montemayor ordenó e fizo ante que finase, e por las cláusulas e dispusiçiones en él contenidas"13. La adquisición onerosa constituía otra de las modalidades para lograr una villa o lugar en señorío, y, del mismo modo, se observa la necesaria argumentación justificativa en la toma de posesión: "Et luego, el dicho señor Ferrand Álvarez, dixo que por quanto el dicho lugar del Torrico era suyo, por título de conpra que dél avía fecho..." ${ }^{4}$. Toda compra implicaba una renuncia de sus derechos, por parte del anterior titular, pero existían además, otras fórmulas específicas de cesión de señoríos, como la cesión de "feudo": así se observa en los trámites de entrada en el señorío por parte de don Juan Pimentel, conde de Benavente, en abril de 1461, de las feligresías de la tierra de Aguiar, por "la dicha carta del dicho feudo", otorgada por el arzobispo de Santiago, don Rodrigo de Luna, que se la entregó "por feudo, para él e sus fijos e herederos e supçesores"

\footnotetext{
${ }^{13}$ El documento se encuentra en el Archivo Histórico Nacional, Nobleza, Frías, leg. 1340, $n^{\prime \prime} 5$. Acerca de los señores de Montemayor, línea familiar desgajada del tronco del linaje de los Fernández de Córdoba, puede verse mi libro Nobleza y señoríos en el reino de Córdoba. La Casa de Aguilar (siglos XIV y XV). Córdoba, 1979.

${ }^{1+}$ Toma de posesión del señorío del lugar del Torrico, por don Ferrán Álvarez de Toledo, el 2 de abril de 1447, localizado en el Archivo Histórico Nacional, Nobleza, Frías, leg. 1326, $\mathrm{n}^{0}$ 11. En este caso, sin embargo, el hecho de la compra siempre resultó un tanto oscuro, porque el documento acreditativo nunca fue presentado por los sucesivos titulares del linaje, de modo que tal circunstancia fue utilizada mucho después, en el contexto de las tensiones y reclamaciones desarrolladas, por parte de los vasallos, acerca de los derechos y tributos requeridos por los señores: ver $\mathrm{M}^{\mathrm{a}}$ Concepción QuINTANILLA RASO, Pechos y derechos agrarios y lógica señorial. Precisiones desde el ámbito toledano, en "Historia Instituciones Documentos", 25 (1998), pp. 497-510, en el que me ocupo, entre otros, del caso específico del señorío del lugar de Torrico.

${ }^{15}$ Archivo Histórico Nacional. Nobleza, Osuna, leg. 516-3". A propósito de los Pimentel, señores de Benavente, acaba de publicarse la tesis doctoral de 1980 de Isabel BECEIRO PITA, con el título de El condado de Benavente en el siglo XV. Salamanca, 1998.
} 
Finalmente, otra situación de traspaso de villas señoriales correspondía a la renuntiatio in favorem, por razones diversas - generalmente de parentescoalgo particular, que obligaba a presentar el correspondiente documento acreditativo; así sucedió, por ejemplo, en el señorío de Saldaña, de la que el arzobispo de Toledo hizo "donaçión e traspasaçión"a su sobrino Diego Gómez de Sandoval, en $1418^{16}$; o cuando don Juan Pacheco renunció al señorío de Chinchilla, Belmonte, y otras villas del marquesado de Villena, en abril de 1468, en favor de su hijo, el cual, al tomar posesión de las villas, presentó e hizo leer el documento, en el que el maestre de Santiago decía lo siguiente: "A los conçejos...e omes buenos....sepades que nos enbiamos ende a don Diego López Pacheco, nuestro amado fijo, para que desde agora para después de los días de nuestra vida...ayades de reçibir e reçibades por vuestro señor ...e le dedes e presentedes la obediençia e fidelidad que como a señor vuestro devedes dar e presentar", incluyendo un mandato explícito a sus vasallos, relacionado con la aceptación del nuevo señor ${ }^{17}$.

\section{Presencia de los protagonistas}

La documentación refleja en muchos casos el protagonismo señorial directo en las ceremonias: "paresçió y presente el dicho señor"18. Dicha presencia podía tener una significación compleja, al menos doble: por un lado, en su sentido de aparición, puede valorarse como una actitud de exhibición intimidatoria; sin embargo, en casos como éste conviene también tener en cuenta que, en su dimensión de desplazamiento, podría indicar un deseo de aproximarse a los vasallos para practicar una captatio benevolentiae, claramente relacionada con las tácticas de integración, y las actitudes paternalistas puestas en juego con frecuencia en el tardo medievo por la

\footnotetext{
${ }^{16}$ Ver Archivo Histórico Nacional, Nobleza, Osuna, leg. 1334, $\mathrm{n}^{\circ}$ 9: transcrito en el Apéndice documental de la obra "Orígenes de la Monarquía Hispánica", ob. cit., doc. 14, pp. 425-428.

${ }^{17}$ Se trata de un documento fechado en Arévalo, el 20 de abril del citado año, y cuyo traslado se inserta en la toma de posesión de la villa y fortaleza de Sax, por don Diego López Pacheco, el 4 de junio de 1468: Archivo Histórico Nacional, Nobleza, Frías, leg. 666, $\mathrm{n}^{\circ} 4$. Lo mismo sucedió en el caso de Hellín, cuya toma de posesión se produjo el 27 de mayo de 1468, por don Diego, en virtud de la renuncia de su padre: ibídem, leg. 666, $\mathrm{n}^{\circ} 2$.

${ }^{18}$ De esta forma se expresa, por ejemplo, en la toma de posesión de las feligresías de la tierra de Aguiar por don Juan Pimentel, documento citado supra, nota 15.
} 
nobleza señorial, aunque, en definitiva, orientadas, al mismo fin de integración y control social.

En otras ocasiones, diversas circunstancias determinaban la decisión de encomendar la gestión a una persona de su confianza, miembro de su entorno clientelar, de condición noble - al menos, hidalgo-, que llevaba a cabo el ritual correspondiente, actuando mediante una carta de poder que se leía en el inicio de la ceremonia ${ }^{19}$. Tal vez podría pensarse en la repercusión de esta circunstancia en la entidad del significado simbólico, que podría verse alterado, o disminuido, cuando la ceremonia se veía privada de la actuación directa del titular del señorío; así se observa en el caso de la toma de posesión de Saldaña, uno de los más antiguos testimonios de estos actos, documentado en 1418, en el que Juan Carrillo de Toledo, actuó como procurador del adelantado mayor de Castilla en la toma de "la tenençia e posesión vel casy de la dicha villa, e de su castillo e torres fuertes, e de sus aldeas, e vasallos, e términos", que se realizó sin ninguno de los elementos integrantes del código gestual acostumbrado ${ }^{20}$. No obstante, la lectura de otros documentos que recogen la actuación de procuradores, conducen a desechar esta hipótesis, por la similitud en los ritos y ceremonias respecto de las realizadas por los señores directamente ${ }^{21}$.

La presencia vasallática - vecinos y "hombres buenos"- resultaba imprescindible en estos actos en los que se producía la recepción del señor,

\footnotetext{
${ }^{19} \mathrm{De}$ los numerosos testimonios de estas frecuentes cartas de delegación, entregadas por señores, a miembros de su clientela, podemos mencionar la otorgada por don Gastón de la Cerda, hijo de don Luis de la cerda, conde de Medinaceli, a su criado Luis de Aguilera, el 26 de enero de 1442, "para que por mí e en mío nombre podades tomar e tomedes la tenençia e posesión çyvil e natural de la mi villa de Ençiso e de su tierra, e de los mis logares de Varca e Fresno": Archivo Ducal de Medinaceli, Sección Medinaceli, leg. 54, $\mathrm{n}^{\circ} 41$, transcrito por $\mathbf{M}^{\mathrm{a}}$ Luisa PARDo RODRiguez en el extenso e interesante Apéndice documental de su ob. cit. doc. 184 , pp. $433-435$.

${ }^{20}$ Documento del Archivo Histórico Nacional, Nobleza, Osuna, leg. 1334, n” 9, ya citado. Es posible también que esa falta de expresividad en los gestos - aunque sí se dieran todos los requisitos formularios-, pudiera deberse también a su fecha relativamente temprana, en 1418, porque, si bien existen testimonios de ceremonias de este carácter en el siglo XIV -ver, por ejemplo, los documentos 41, 74, y 86, del libro de $\mathrm{M}^{\mathrm{a}}$ Luisa PARDO RODRíGUEZ, ob. cit., pp. 178-179, 220-222, y 232-234, fechados en 1376, 1379 y 1381 , respectivamente-, lo cierto es que no debieron quedar bien perfiladas hasta los años centrales del siglo XV.

${ }^{21}$ Ver, por ejemplo, la toma de posesión de Cañete de las Torres, realizada por Pedro de Vargas, en nombre del señor, don Alfonso Fernández de Córdoba, el 4 de mayo de 1424, y en la que, como luego se analizará, se incluyeron numeros gestos, dentro del significado ritual de estos actos: Archivo Ducal de Medinaceli, Sección Priego, leg. 34, $n^{\circ} 7$, transcrito en $\mathbf{M}^{\mathrm{a}}$ Concepción Quintanilla Raso, Cañete de las Torres en la Baja Edad Media, ob. cit., pp. 102-106.
} 
obedeciendo a un mandato de la instancia de poder correspondiente: " $E$ mando... que vos ayan e reçiban por su señor de la dicha villa...e de su tierra"22. No actuaban sólo en calidad de testigos, sino que su protagonismo era, por razones obvias, indispensable. En muchos casos se documenta una participación muy amplia de habitantes, que constituyen una larga relación de asistentes, mencionados con la indicación de sus nombres y su correspondiente situación socio-profesional, como sucede en la descripción de la toma de posesión del señorío cordobés de Montemayor, en 1459, por Martín Alfonso de Montemayor, donde se habla de la presencia física de zapateros, sastres, cardadores, hortelanos, ceperos, meleros, etc. ${ }^{23}$. En otras ocasiones, tras incluir una larga relación de vecinos asistentes, se llama la atención acerca de la presencia generalizada de la población, como en el siguiente ejemplo: "la mayor parte del pueblo de la dicha tierra de Aguiar e feligresías, espeçialmente llamados a su conçejo, de tres días ante.....para resçibir por su señor para sienpre jamás a don Juan Pimentel" ${ }^{24}$.

Por otra parte, en los actos de posesión de los señoríos bajomedievales era habitual la intervención de los oficiales concejiles, en su dimensión institucional; así, alcaldes, alguaciles, escribanos, mayordomos, oficiales en general, participaban activamente en la ceremonia, convirtiéndose en elementos indispensables en el contexto de la representación, en todo lo relacionado al traspaso de funciones de administración y gobierno del señorío. No obstante, el sentido de la presencia alcanzaba un grado distinto, en función del nivel de entidad de la institución concejil, según los casos; así, como luego se indicará, mientras en unas ocasiones el concejo se convertía en el centro de gravedad donde se concentraba la acción, en otras ocasiones, la función de los oficiales concejiles alcanzaba mucho menos entidad, llegando a resultar, en ciertos casos, inexistente.

\section{Escenario}

Uno de los aspectos de mayor interés, y al que no siempre se ha prestado suficiente atención, lo constituye la localización y el significado del

\footnotetext{
${ }^{22}$ Archivo Histórico Nacional, Nobleza, Frías, caja 4, n"16: concesión del señorío de Moya por el príncipe don Enrique a Pacheco.

${ }^{23}$ Archivo Histórico Nacional, Nobleza, Frías, leg. 1340, n 5.

${ }^{24}$ Ibidem, Osuna, 516-3 (11).
} 
escenario donde se procedía a la representación del sistema de relaciones propio de los señoríos bajomedievales. En este punto, observamos que en algunos documentos testimoniales no viene determinada expresamente la localización de la ceremonia, de la que, sin embargo, se dice que había tenido lugar en el sitio donde acostumbraban a reunirse los oficiales del concejo; un lugar que, por otra parte, a veces no se precisaba, aunque, en otras ocasiones sí se hacía, y solía tratarse de una plaza, o las inmediaciones de un edificio religioso. Veamos algunos ejemplos. En primer término, un caso de imprecisión espacial: "En el lugar de Pereyro, que es en tierra de Aguiar, en la feligresía de Sant Salvador, donde han uso e costunbre de se ajuntar concegilmente a fazer sus conçejos e ayuntamientos"; en otras ocasiones sí se indica el lugar donde se reunía el concejo: "En la villa de Sax....estando ayuntados a conçejo, a boz de pregón, segund que lo han de uso e de costunbre, en el portal de la plaça desta villa"; o "En la villa de Saldaña......estando en la iglesia de Sant Estevan, que es en la plaça de la dicha villa, e estando y el conçejo e omnes buenos de la dicha villa de Saldaña, ayuntados a conçejo a campana tañida, segunt que lo han de uso e de costunbre de se juntar" ${ }^{25}$. Conviene señalar, respecto a esto, que el desplazamiento del señor, o su prepresentante, hasta el ámbito propiamente concejil, indica, en principio, un notable grado de desarrollo de dicha institución, aunque no necesariamente tuviera que influir en la situación de poder alcanzada por el titular del señorío.

Ahora bien, pese a todo lo anterior, hay que tener en cuenta un hecho que no ha sido suficientemente destacado en la historiografía sobre estas cuestiones, y que, sin embargo, resulta a todas luces, evidente, y es la frecuencia con que estos actos se desarrollaban en un espacio dotado de un profundo significado de poder y autoridad, como era el castillo, o fortaleza. Resulta innegable la importancia determinante que la adquiría en estos actos la fortaleza señorial, en su función de locus, o espacio simbólico por excelencia. El castillo, como edificio más representativo de la topografía del poder nobiliario, encarnaba todas las facetas integrantes de la relación de preeminencia y sujeción, respectivamente, sobre la que se sustentaba el

\footnotetext{
${ }^{25}$ Ver, respectivamente, Archivo Histórico Nacional, Nobleza, Osuna, leg. 516, n 3 (11), (doc. $1^{\circ}$ ); ibídem, Frías, leg. 666, $\mathrm{n}^{\circ} 4$; ibídem, Osuna, leg. 3334, $\mathrm{n}^{\circ} 9$; algo semejante pasó en la toma de posesión de Morera (Badajoz), "estando çerca de la yglesia de Sant Lorenço del dicho lugar, ayuntados en conçejo", documento del Archivo Ducal de Medinaceli, Sección Feria, leg, 58, $\mathrm{n}^{\circ} 15$, transcrito por Fernando MAzo RoMERo, El Condado de Feria (13941505), Badajoz, 1980 p. 581.
} 
orden señorial, por lo que es fácil entender que se trataba del escenario más adecuado para la representación. Y dentro de él, concretamente, la torre del homenaje desempeñaba el papel fundamental, convertida en un signo icónico dotado de todos los ingredientes necesarios, incluso físicos, -altura, tamaño, grandiosidad - para la función de mensaje que toda arquitectura desempe$\tilde{n} a^{26}$.

Dicha realidad no ha sido aún suficientemente destacada en los estudios sobre las tomas de posesión, y, sin embargo, es preciso afirmar que en la mayoría de ellas, el castillo era un lugar decisivo, y la tenencia y posesión del mismo estaba dotada de entidad propia, de modo que se desarrollaba en un acto, a veces, previo a la de la villa, con un claro y lógico protagonismo del alcaide, como figura muy destacada en el marco de las relaciones entre los señores de vasallos y la clientela más próxima a su figura. En cuanto a su papel como escenario, a veces, incluso el concejo se encontraba reunido en dicho lugar, y era allí donde se reunía con el señor o su procurador, para darle la posesión ${ }^{27}$. Resultaba muy habitual la indicación, al principio del documento, de la situación de los protagonistas "ante las puertas del dicho castillo e casa fuerte" - en la toma de posesión de Torrico, en 1447, por Ferrán Álvarez de Toledo--, o "en par del castillo e fortaleza de la dicha villa" - por ejemplo, en Montemayor, el 20 de mayo de 1459- de forma que los actos iniciales se celebraban allí, y los primeros

\footnotetext{
${ }^{26} \mathrm{La}$ enumeración de trabajos acerca de la multifuncionalidad del castillo, -desde la dimensión militar, hasta su significado político, jurisdiccional, como sede del tribunal de justicia señorial, o incluso económico, como centro de percepción de rentas y tributos, y, en suma, de su sentido como expresión máxima de los intereses y valores de la clase nobiliaria- sería interminable. Algunos títulos recientes ofrecen claras interpretaciones acerca del sentido polisémico de los castillos, como, por ejemplo, la obra colectiva que lleva por título La fortaleza medieval. Realidad y símbolo, "Actas XV Asamblea General de la Sociedad Española de Estudios Medievales”, J.A. Barrio, y J.V. Cabezuelo edits., Murcia, 1998, donde destacan, por su contenido más relacionado con el tema aquí tratado, entre otros, los artículos de Etelvina FERnÁndez GonZÁlez, El Castillo y la iconografía en la Edad Media Hispana, pp. 215-242,; Fernando CASTILLO Y CÁCERES, El Castillo-Palacio de Escalona, corte y escenario de poder de Álvaro de Luna, pp. 281-292; Enrique VARELA Aguï, La dimensión simbólica del castillo plenomedieval, pp. 345-356; y $\mathrm{M}^{\mathrm{a}}$ Isabel PÉREZ DE TUDELA, El castillo señorial. En su contexto histórico, pp. 163-176. De esta última autora, ver también, El castillo en la simbología de las Órdenes Militares, en "Historia Social, Pensamiento Historiográfico y Edad Media. Estudios en Homenaje a Ábilio Barbero", Ma I. Loring, edit., Madrid, 1997, pp. 299-310.

${ }^{27}$ Así se indica en la toma de posesión de Cañete de las Torres - En la villa de Cañete....estando en el castillo de la dicha villa, ayuntados en su cabildo e conçejo, llamados por su portero, según que lo han de uso e de costunbre": Archivo Ducal de Medinaceli, Sección Priego, leg. 34, $\mathrm{n}^{\circ}$ 7: ver $\mathrm{M}^{\mathrm{a}}$ Concepción QuinTANIlla Raso, Cañete de las Torres en la Baja Edad Media, ob. cit., p. 102.
} 
gestos de poder se realizaban en relación con la tenencia de estos edifi$\operatorname{cios}^{28}$.

Además, hay que hacer notar una circunstancia de interés, y es que, en algunos casos, la posesión del castillo englobaba la de la villa, que quedaba así implícitamente integrada, en función de los actos que se desarrollaban en dicho edificio. Tal situación tuvo lugar en la toma de posesión de la Isla de León, por parte de Alonso de Torres, contador de don Rodrigo Ponce de León, en su nombre, el 12 de mayo de 1511, en una ceremonia desarrollada en la torre-homenaje del castillo, con sentido exclusivo, sin mencionar a la villa, lo cual es interpretado por Franco Silva desde la óptica de la inexistencia de habitantes, y la carencia de organización concejil en este lugar ${ }^{29}$. No obstante, en otros casos no cabe dicha interpretación, pues el papel determinante desempeñado por la fortaleza señorial no implicaba insuficiente desarrollo institucional, o escasa población; así, al contrario, el señorío cordobés de Montilla, era uno de los más importantes en el estado señorial de la Casa de Aguilar, en cuanto a densidad de habitantes, desarrollo económico, organización institucional, a la vez que constituía uno de los ejemplos más representativos de los centros de poder del linaje, cuando don Alfonso Fernández de Córdoba, el 2 de marzo de 1455 , procedió a tomar posesión de la villa, en una ceremonia realizada por completo en la fortaleza, y desde la óptica de este edificio, cuyo significado absorbía al de la propia villa ${ }^{30}$.

\footnotetext{
${ }^{28}$ Respectivamente, Archivo Histórico Nacional, Nobleza, Frías, leg. 1326, n” 11: e ibídem, Frías, leg. 1340, $n^{\circ} 4$. Recientemente, un extenso trabajo de investigación ha venido a ofrecer una panorámica generalizada del funcionamiento de la tenencia de fortalezas como institución, y del alcance político-social, en el marco de relaciones monarquía-nobleza-ciudades. en la Castilla bajomedieval: Concepción CASTRILlo Llamas. La tenencia de fortalezas en la Corona de Castilla durante la Baja Edad Media (siglos XIII-XV), Tesis doctoral, Universidad Complutense, Madrid, 1997.

${ }^{29}$ Alfonso Franco Silva, La Isla de León en la Baja Edad Media. Cádiz. 1995. concretamente, pp. 21-22, en que se hace una selección de párrafos del documento que recoge la ceremonia, a propósito de la cual el autor insiste en que no había villa poblada, ni concejo, de forma que el señorío sólo tenía un centro de poder, que era el castillo.

${ }^{30} \mathrm{En}$ el testimonio documental se lee lo siguiente: "dentro en la torre mayor del omenaje que es en el castillo desta dicha villa, en la bóveda más alta de la dicha torre”, el señor manifestó ante el alcaide y los testigos presentes, que "quería entrar e tomar e aprehender la posesyon cevil e natural e actual del dicho castilllo et fortaleza et villa, a boz e a nonbre de todas las tierras e terminos e heredamientos de la dicha villa de Montilla”, y lo hizo sólo mediante el rito específico y exclusivo de la toma de posesión de dicho edificio, de forma que la villa se consideraba englobada, como extensión del mismo. Archivo Ducal de Medinaceli, Sección Histórica, leg. 381 (caja 39), n" 40. Ver la transcripción completa del mismo en "Orígenes de la Monarquía Hispánica”, ob. cit., Apéndice documental, doc. 16, pp. 429-430. Ver también
} 


\section{LA PUESTA EN ESCENA: FORMALISMO Y SIMBOLISMO}

El formalismo de la palabra, - oral o escrita-, de los objetos, y de la acción, era básico en estos actos ceremoniales. Para la correcta interpretación de los mismos no conviene diferenciar, ni contraponer, el distinto valor alcanzado por cada uno de esos elementos, sino, por el contrario, incorporarlos todos ellos en una teoría del gesto, partiendo de un concepto amplio, en el que se da cabida a movimientos, posiciones, palabras, $y$, naturalmente, objetos, y en la que la gestualidad aparece entendida en su doble dimensión de eficacia práctica y simbólica. Para ello, se ponían en juego todo un conjunto de actitudes -entendiendo por tales la mezcla de situaciones, posiciones, movimientos, y expresiones- que favorecían la relación entre los protagonistas, mediante la puesta práctica de un sistema complejo de contacto físico, y simbólico, entre personas, y entre éstas y una serie de objetos representativos ${ }^{31}$.

Durante la ceremonia, señor y vasallos pronunciaban palabras -según fórmulas establecidas-, ejecutaban movimientos corporales -sencillos, pero expresivos-, y arrebatan-entregaban, o devolvían-recibían, respectivamente, objetos - con contenido práctico, pero, a la vez, cargados de significado-. Todos los elementos que se ponían en juego en tales actos correspondían a distintas formas de lenguaje - oral, escrito, visual, gestual-, destinadas a representar la aprehensión por el señor de los contenidos materiales, tangibles, del señorío, así como de los intangibles, y, por parte de los vasallos, a significar la obediencia y sujeción. Pese a los diferentes grados de expresividad que se aprecian en los distintos documentos, respondían a un sistema codificado, en lo esencial.

mi artículo sobre Contenidos, símbolos e imágenes del poder nobiliarios en la Montilla bajomedieval, ob. cit.

${ }^{31}$ El valor de los gestos en una sociedad penetrada de simbolismo, como fue la del Occidente medieval, es algo fuera de toda duda, y que muchos autores se han encargado de destacar. Entre ellos. Le Goff, que, en 1976, ya daba noticia de la elaboración de un fichero de gestos y gestualidad. tomando como base fuentes de diverso carácter, como documentos, textos jurídicos, obras literarias, y testimonios iconográficos: ver Jacques LE GOFF. Les gestes symboliques, ob. cit. p. 782. Bastantes años más tarde. Jean-Claude SCHMITT, uno de los participantes en estas investigaciones - junto con Le Goff, Bonne, y Pastoreau-, ha expuesto sus consideraciones en una obra de interés general, aunque referida a la tardoantigüedad, y la Alta Edad Media, y planteada desde una perspectiva muy centrada en el ámbito religioso y eclesiástico: La raison des gestes dans l'Occident médiéval, Paris, 1990. 


\section{Actitudes y gestos señoriales}

En primer término, hay que señalar la necesaria manifestación explícita de la intencionalidad del señor, que le llevaba a manifestar ante testigos, su deseo de proceder en ese momento a la toma de posesión del señorío, - "Et luego el dicho señor Ferrand Álvarez dixo que....venía al dicho lugar del Torrico con ánimo e proposito de tomar la posesión dél"es decir, de entrar en la justa posesión del mismo, la que se obtenía según derecho, y con plena autoridad ${ }^{32}$.

Las posturas, acciones, y fórmulas pronunciadas en dicho contexto se iniciaban con la utilización de un objeto, concretamente un escrito, en representación de los justos e derechos titulos, que ponía en marcha todo el dispositivo ceremonial, tras lo cual se realizaba la petición a los vasallos para que participasen en los actos dirigidos a la obtención de la "tenençia e posesión e propiedad e verdadero señorío" del lugar ${ }^{33}$. El simbolismo corporal alcanzaba un valor determinante, y entre los elementos que entraban en acción destacan, por un lado, los pies como elemento indicador de la posesión corporal del señorío, que se señalaba en los documentos mediante expresiones como ésta: "entró corporalmente de pies" ${ }^{34}$; y, naturalmente, las manos, elemento de simbología polisémica, que expresa fuerza, y al mismo tiempo, acercamiento y protección, destinadas a realizar numerosos gestos de ostentación de poder - en concreto, la mano derecha, receptora del beso de dependencia vasallática, o la privación de los objetos que simbolizaban los oficios, o, incluso la expulsión de los vasallos de la villa y castillo-, pero también de acercamiento - la imposición o mezcla de manos, la entrega de los signos icónicos que representaban los oficios, o la entrada de nuevo

\footnotetext{
${ }^{32}$ Toma de posesión del lugar toledano de Torrico, Archivo Histórico Nacional, Nobleza, Frías, leg. $1326 \mathrm{n}^{\circ} 11$

${ }^{33}$ Expresiones tomadas de la ceremonia correspondiente al señorío de Montemayor, doc. cit. Archivo Histórico Nacional, Nobleza, Frías, leg. 1340, n 4. El texto expreso de la petición se recoge en la toma de posesión de Cañete de las Torres, en la que Pedro de Vargas, en nombre del señor, don Alfonso Fernández de Córdoba, "dixo que pedía e pidió a los dichos alcayde e alcalldes e alguasil e ofiçiales e omes buenos de la dicha villa que le fiziesen los omenajes e juramento e fidelidad que en tal caso eran tenudos, e todas las otras insinias e onrras en señal de señorío, que de derecho se devían faser": $M^{a}$ Concepción QuinTanilla Raso, Cañete de las Torres, ob. cit., pág. 103.

${ }^{34}$ Archivo Histórico Nacional, Nobleza, Frías, leg. 1340, $\mathrm{n}^{\circ} 5$, referente a la villa de Montemayor.
} 
de los vasallos en el castillo o en la villa, tomándolos el señor por sus manos-. Asimismo, interesa subrayar el significado de la propia posición adoptada en cada instante por el señor: de pie, y en movimiento en ciertos momentos, y, por el contrario, sentado y en reposo, cuando realizaba las audiencias judiciales, o cuando recibía los gestos de obediencia y fidelidad de sus vasallos ${ }^{35}$.

La ceremonia se articulaba en una serie de actitudes señoriales, encaminadas a la representación simbólica de cada uno de los planos de su autoridad. En lo referente a los derechos territoriales -más allá de la problemática de la entidad del ius eminens en el señorío bajomedieval que queda fuera de este estudio-, resultaba muy común el paseo del señor, a caballo, o, generalmente, a pie, más o menos prolongado por la villa y el término, pero siempre cargado de un claro significado de posesión, derivado del gesto de "hollar con los pies" expresado ante los testigos que lo presenciaban; un significado que, además, se subrayaba a menudo con gestos de verdadera propaganda de los derechos señoriales sobre la tierra y la producción que adquiría en ese momento, puestos de manifiesto en los puñados de tierra, piedras, hierbas, o ramas arrancadas con su propia mano, la colocación de lindes en el término, la acción de beber agua, o comer frutos, o incluso la destrucción de tejas o materiales de los edificios. A título de ejemplo, el paseo por el término de Torrico, durante la toma de posesión, incluyó, como gestos más destacados, los siguientes: "andovo por todo el dicho término redondo, e montes, e çerros, e valles dél, e fizo poner e puso çiertos mojones e límites entre los términos de los lugares comarcanos....e cortó con un cochillo que en sus manos traya çiertas ramas de enzinas e robles questán en la dehesa que dizen de Valdepalaçios"; y en el caso de Montemayor se dice, respecto a la villa, que "usando de la dicha posesión, anduvo por la dicha villa de Montemayor, commo señor della de unas partes a otras", y, en cuanto al término, "en presençia de los testigos entró corporalmente de pies dentro de los heredamientos....e anduvo...e cortó de

\footnotetext{
${ }^{35}$ Sobre el sentido múltiple de la gestualidad referida a las manos, ver Jacques LE GoFF, ob. cit., pág. 688, donde afirma que constituye uno de los grandes capítulos del simbolismo medieval, y universal. Una importancia destacada le concede también Jean-Claude SCHMITT, ob. cit., en el cap. III, que, aunque referido al ámbito religioso - "La main de Dieu"-. contiene consideraciones generales sobre el profundo y múltiple significado jurídico y simbólico de la mano. Desde una perspectiva iconográfica, interesa también la obra de François GARNIER, Le langage de l'Image au Moyen Age. I. Signification et symbolique. II Grammaire des gestes, Paris, 1982 ( $\left.2^{\mathrm{a}} \mathrm{ed}.\right)$, y 1989 , respectivamente.
} 
las yervas que estavan nasçidas en las dichas tierras, e puso piedras e por los lindes e mojones...en señal de posesión" ${ }^{36}$.

Aspecto fundamental en el señorío tardomedieval era la capacidad de administración y gobierno derivada de la dimensión jurisdiccional. En los actos ceremoniales, esta capacidad señorial se ponía de relieve a través de algunos gestos. que correspondían a las distintas facetas. Así, por ejemplo, el derecho de nombramiento de oficiales se significaba mediante la toma por el señor de los objetos representativos de cada cargo - varas de la justicia, escribanías, llaves, cadenas y prisiones de la cárcel, etc.-, a los individuos que los ejercían, haciendo gala de su posición autoritaria en la propia dimensión formal de los gestos, que a veces son descritos como una acción más fuerte, consistente en arrebatar; de forma complementaria, el titular del señorío procedía a entregar dichos objetos a los elegidos por él, que, en muchas ocasiones, se trataba de las mismas personas, quienes así quedaban investidos de sus poderes por el nuevo señor. Todo esto se observa con claridad en la descripción del ritual en el caso de la villa cordobesa de Montemayor: "quitó e privó e sospendió de los ofiçios de alcalldías a los dichos ....que usavan de ofiçio de alcalldes, e al dicho.... alguazil, del dicho oficio de alguaciladgo, e a los dichos .... de los dichos ofiçios de juraderías, e a ....de los dichos ofiçios de escrivanías públicas, e los defendió e mandó que non usasen más de los dichos ofiçios...e asy quitados e privados, el dicho Martín Alfón de Montemayor, commo señor de la dicha villa e por sy mismo, los tornó a poner e elegir, e puso e eligó por sy en los dichos ofiçios" ${ }^{37}$. En los casos en que el lugar no había alcanzado el suficiente

\footnotetext{
${ }^{36}$ Respectivamente: Archivo Histórico Nacional, Nobleza, Frías, leg. 1326, n" 11: ibídem, Frias, leg. 1340, n" 5. Entre otros casos destacados, por su mayor expresividad en este tipo de gestos está el documento de toma de posesión de Gandul y Marchenilla, el 7 de marzo de 1492 , por parte del criado del condestable Bernardino de Velasco, conservado en el Archivo Histórico Nacional, Nobleza, Frías, cajón 77, analizado por Alfonso Franco Silva, Gandul y Marchenilla. Un enclave, ob, cit., pp. 185-188, donde se explicitan todos estos gestos: “anduvo por la villa a piè y cabalgado....quebró dos texas....arrancó piedras.... fue a la fuente principal de la villa de Gandul y bebió el agua della....quebraua rramos de árboles.....coxió ciertas naranxas e comió de una dellas....cortó de unas parras e de unos almendros e comió de las almendras, e arrancó de las yeruas en señal de posesión”. También la toma de posesión de Fuenteovejuna, en 1452, en nombre del maestre de Alcántara incluyó el recorrido a pie por la villa. según comenta Emilio CABRERA MUÑOZ. El condado de Belalcázar (1444-1518), Córdoba. 1977. pp. 139-140, una breve descripción, en la que el autor alude a paralelos de estos ritos en el capitulo XLV, de la segunda parte de El Quijote.

${ }^{37}$ Archivo Histórico Nacional, Nobleza, Frías, leg. 1340, n" 5. En este caso concreto no se hace alusión a los objetos que representaban los cargos concejiles - varas de la justicia, llaves de la cárcel, escribanías, etc.-: sin embargo, la importancia de estos elementos era
} 
desarrollo institucional de su concejo, el señor iniciaba esta parte del ritual con el nombramiento de oficiales, para luego destituirlos, subrayando su autoridad señorial, y, finalmente, volverlos a nombrar ${ }^{38}$

En este contexto, la faceta directamente relacionada con el ejercicio de la jurisdicción civil y criminal, alcanzaba un sentido más destacado, y requería de todo un conjunto de gestos especiales, encaminados a poner de relieve esta capacidad señorial. Entre ellos cabe destacar la construcción de horcas, que aparece documentada en algunos casos, con un significado práctico, pero sobre todo simbólico: "paresçió el dicho señor Ferrand Álvarez e dizo que con ánimo e con propósito de aver para sy la posesión de la dicha juridiçión çevil e creminal, alto e baxo, e mero e misto ynperio, fizo levantar e poner e puso una forca de tres palos de madera dentro del dicho término e territorio del dicho lugar del Torrico, e fizo colgar una soga desparto de la dicha forca" ${ }^{39}$. A pesar de algunos problemas de interpretación acerca de la adecuación entre denominación y la funcionalidad penal concreta, $-\mathrm{y}$, en relación con ello, de las diferencias entre horcas, picotas y rollos-, el sentido de la horca como símbolo jurisdiccional, no presenta ninguna duda. El levantamiento de la misma, construida de madera, como señala el documento mencionado, con dos palos hincados en el suelo, más otro tercero para trabarlos, se presentaba, como un gesto, con ciertas formalidades, de claro significado del ejercicio de la administración de justicia por parte del señor, o de sus agentes. A veces, en algunos actos de toma de posesión, aún existiendo dicho elemento señalador de la acción de la justicia, el señor podía decidir su cambio de emplazamiento; en este sentido, es cierto que el material utilizado, -antes de la generalización de

determinante: ver, a este respecto, la lista de noventa y ocho objetos simbólicos del Glosario de Du CANGE, incluida como apéndice en el artículo de Jacques LE GoFF, ob cit

${ }^{38}$ Contamos con un ejemplo muy ilustrativo, el del señorío del lugar de Torrico, donde se pone de relieve tal situación: Archivo Histórico Nacional, Nobleza, Frías, leg. 1326, n“ 11.

${ }^{39}$ Ibidem. Pese a las afirmaciones de Isabel BECEIRO PITA, en El escrito, la palabra, ob. cit., p. 75 , no hay que avanzar tanto en el tiempo para encontrar testimonios de la presencia de horcas o picotas, como elemento distintivo del señorío jurisdiccional, pues, aparte del caso de Torrico, de 1447. existen testimonios de la primera mitad del siglo XV: yo misma he documentado y publicado hace años un ejemplo, referente a Cañete de las Torres, fechado en 1424: M $^{\mathrm{a}}$ Concepción QuINTANIlla RASO, Cañete de las Torres, ob. cit., pág. 105. En la toma de posesión de Hontanaya, aldea de Alarcón, en 1445 también se alude a esto: "E después de lo susodicho en este dicho día en la dicha Fontanaya, el dicho Gonzalo de Soto, continuando la dicha posesión, por nombre del dicho señor marqués, puso e asentó e fizo poner e asentar una forca en un cerro que es entre dos caminos que van de Fontanaya a Almonacir e a la señuela de tres palos de madera”: Miguel RODRíguEz LlOPIS, ob. cit., p. 355 
las de piedra-, favorecía la provisionalidad, de tal modo que, una vez aplicado el castigo, el objeto penal podía ser desmontado, o trasladado; no obstante, esas decisiones en relación con su desplazamiento, hay que interpretarlas como gestos del nuevo señor encaminadas a subrayar su propio poder al respecto ${ }^{40}$.

En muchos casos, además, se producía un ritual de representación de la figura del señor como juez, mediante su gesto de actuar en audiencia, y el desarrollo de procesos judiciales bajo su jurisdicción, en el contexto de las cereremonias. Era normal, por tanto, ver al señor, sentarse en juicio en la plaza pública de la villa, como se recoge en testimonio en la toma de posesión de Sax, cuando don Diego López, en presencia del escribano y los testigos, acudió "a la audiençia de la tarde, se asentó en el portal de la dicha villa en la plaça, e tomó e aprehendió la dicha posesyón de la dicha villa de Sax" ${ }^{41}$. También lo era la celebración de un juicio completo, que acababa con la sentencia señorial ${ }^{42}$. Por otra parte, a veces se incluían gestos de clemencia, que más allá de la generosidad señorial, plasmada en característicos actos de gracia en el inicio de su mandato, formaban parte de la dimensión de espectáculo propagandístico que entrañaba la representación de la vertiente jurisdiccional del señor ${ }^{43}$. En otras ocasiones, en las que la toma de posesión se realizaba mediante procurador, lo que se observa es la

\footnotetext{
${ }^{40}$ Un caso muy patente, en la toma de posesión de Cañete de las Torres, en 1424, en que el representante señorial, Pedro de Vargas, ordenó al alguacil "que asentase una forca de madera çerca de la dicha villa, en nonbre del dicho Alfon Ferrandez, e el dicho alguasil dixo que puesta estava, e el dicho Pedro de Vargas mandóle que la mudase de aquel lugar a otro, e el dicho alguasil dixo que le plasía todo esto que dixo que fasía e fiso en señal de posesion e por posesion que tomava de la jurediçion de la dicha villa": $\mathrm{M}^{\mathrm{a}}$ Concepción QuiNTANILLA RASO, Cañete de las Torres, ob. cit., p. 105. El estudio de las horcas. o picotas presenta un alto interés. y permite múltiples posibilidades de enfoque, a partir de diferentes fuentes de investigación, desde las literarias, hasta las arqueológicas o artísticas, jurídicas, y, desde luego, diplomáticas.

${ }^{41}$ Archivo Histórico Nacional, Nobleza, Frías, leg. 666, n 4.

${ }^{12}$ Asi sucedió en Torrico, donde se celebraron actos judiciales, a propósito de una deuda de 2.000 maravedíes, para cuyo pago que se solicitaba un plazo: "paresçieron antel dicho señor ....cavallero vezino de la villa de Oropesa, e ....vezino del dicho lugar Torrico.....et el dicho señor dixo que le dava el plazo para responder": Archivo Histórico Nacional. Nobleza, Frías, leg. 1326, $n^{\circ} 11$.

${ }^{43}$ Un ilustrativo ejemplo de clemencia señorial, en la ceremonia de Cañete: $\mathrm{M}^{\mathrm{a}}$ Concepción Quintanilla Raso, Cañete de las Torres. ob, cit., p. 105, en que se recoge el caso de un vecino encarcelado por una deuda de 6 cahices de trigo al anterior titular del señorío, que, por su edad avanzada, pidió ser liberado, y encontró la respuesta favorable del procurador del señor, quien, tras recibir a su fiador, "mandó soltar al dicho Pero Lopes, e el dicho alguasil soltólo luego".
} 
puesta en marcha del aparato judicial del señorío, mediante la intervención de los oficiales correspondientes, como se observa en el caso de Montemayor: "Et el dicho Alfón de Mesa (como procurador del señor), en el dicho nombre, tyró de los dichos ofiçios de alcalldías a los dichos alcalldes, e luego los tornó a poner et asentar en los dichos ofiçios, et los restituyó en ellos...et asy tornados e asentados, començaron luego a judgar pleitos" 44

Entre los elementos integrantes de los aspectos intangibles del señorío se encontraban las atribuciones fiscales, que aparecen muy desdibujadas en las ceremonias de representación. No falta, sin embargo, algún testimonio aislado, por el que el titular del señorío, en prueba de su capacidad, establecía relación directa con un vecino, al que tomaba un signo identificativo de su condición de pechero, concretamente, un elemento de la indumentaria, que, echado sobre el hombro, simbolizaba esta faceta de la sumisión ${ }^{45}$.

Finalmente, en cuanto al simbolismo de acción, es preciso señalar algunos gestos señoriales demostrativos de poder y autoridad, entre los que aparecen como más generalizados la expulsión de los vecinos a la que procedía el nuevo titular del señorío, para aprehender la posesión del mismo en toda su entidad. Así sucedió en la toma de posesión de Hellín, cuando al final de la ceremonia, el procurador que actuaba en nombre del señor "fue en uno con todos los susodichos de suso nombrados a la puerta que dizen de Murçia, que es de la dicha villa, e pidió la llave della al dicho.... alguazil, que la él tenía, la qual le dió, e dada, lançó fuera de la dicha villa a todos los susodichos, e çerró las puertas de la dicha villa, e çerradas dixo que se tenía e tovo por contento de la posesión e señorío de la dicha villa para el dicho señor don Diego López Pacheco, e tornó a abrir las dichas puertas, e metyó por su mano a los dichos"46.

\footnotetext{
${ }^{44}$ Archivo Histórico Nacional, Nobleza, Frías, leg. 1340, n” 4.

${ }^{45}$ Se trata de un valioso testimonio del estado señorial extremeño de Feria, donde Lorenzo Suárez de Figueroa, al tomar posesión de la villa de Morera, se dirigió a un vecino, que actuaba en representación de los pecheros, y "fizo tomar a Alfon Alvarez, vezino pechero del dicho lugar, un suario que tenía en el ombro en señal de prenda de los pechos e derechos": Fernando MAZO ROMERO, ob. cit., p. 581, un testimonio documental que incluye numerosos elementos de lenguaje gestual, por lo que resulta muy expresivo, pese a su concisión y relativa brevedad. Ver la interpretación ofrecida al respecto por Isabel BECEIRO PITA, en El escrito, la palabra, p. 76, en el sentido del simbolismo paralelo con la sumisión representada por la mujer respecto) del marido, manifiesta también en una especie de toca, y con el yugo de los bueyes, un paralelismo tal vez más débil, en este caso.

${ }^{46}$ Archivo Histórico Nacional, Nobleza, Frías, leg. 666, n”2.
} 
Una gestualidad específica se ponía en práctica en las tomas de posesión de los edificios en los señoríos. Resulta interesente, por su particularismo, el caso de las iglesias, cuya posesión se realizaba con un ceremonial propio, en el que entraban en juego los elementos identificativos, -las llaves del edificio, campanas, libros y ornamentos sagrados-, aunque las actitudes y gestos realizados presentan una notable similitud con la situación analizada, incluyendo la expulsión, y posterior admisión, del clérigo del lugar ${ }^{47}$. Mucho más difundidas se encontraban las tomas de posesión específicas de los castillos señoriales. Entre los testimonios inéditos, destaca por su elocuencia el referente a Montemayor, villa donde el señor, literalmente, "entró corporalmente de pies en el dicho castillo e fortaleza de la dicha villa de Montemayor, e anduvo por el dicho castillo de unas partes a otras., lo qual dixo que fazía e fizo en señal de posesión ....e çerró sobre sy las puertas del dicho castillo, e abriólas tomando commo tomó las llaves del dicho castillo a Álvaro de Juera, alcayde ....e apoderóse commo se apoderó del dicho castillo e fortaleza, e de todos los pertrechos e cosas que dentro en él estavan, et asy apoderado...dixo que soltava e quitava al dicho Álvaro de Juera el pleito omenaje que tenía fecho al dicho...su padre, e que ponía e puso por sy e por su alcayde al dicho Álvaro de Juera....e dióle e entrególe las llaves"....tras de lo cual, le tomó el pleito-homenaje al recién investido ${ }^{48}$. En algunos testimonios más expresivos se describe la fórmula del pleito-homenaje, con alusión al gesto señorial de la inmixtio manuum, que pone de relieve la especificidad de la relación, basada en el mayor acercamiento, del señor con el alcaide, en su condición de hidalgo ${ }^{49}$.

\footnotetext{
${ }^{47}$ Un caso muy ilustrativo es el comentado por Alfonso Franco Silva. en Gandul y Marchenilla, ob. cit.. pp. 187-188. en que se refiere a la toma de posesión de la iglesia de Sain Juan de Gandul.

${ }^{48}$ Archivo Histórico Nacional, Frías, leg. 1340, n" 5 . En una toma de posesión complementaria, de esta misma fortaleza, se observa que el procurador señorial "entró luego de pies dentro en el dicho castillo e fortaleza de la dicha villa, e lanço al dicho alcayde fuera della, e cerró las puertas sobre sy. Et después tomólo por la mano, e metiólo dentro, e dexólo en la dicha posesión": Ibídem, Frías, leg. 1340, n“4.

${ }^{49}$ Por ejemplo, así tuve ocasión de observarlo en Cañete de las Torres: "Et luego, en esecuçión, el dicho Pedro de Vargas - que actuaba en nombre del señor- tomó las manos del dicho alcayde Ruy Díaz Çerón, entre las suyas, e díxole..”, $\mathrm{M}^{\mathrm{a}}$ Concención QuinTANILLA Raso, Cañete de las Torres, ob. cit., p. 104. Con todo, el testimonio más explícito que he tenido ocasión de analizar es el de la toma de posesión del castillo del señorío de Montilla Contenidos, simbolos e imágenes, ob. cit.; he transcrito el documento en el Apéndice documental de "Orígenes de la Monarquía Hispánica", op. cit., doc. 16, pp. 429-430.
} 
Todo lo anterior se inscribe en un marco de representación encaminado a subrayar las bases y contenidos del poder señorial, pero a veces dicha perspectiva se complementaba con la inclusión de alguna fórmula explícita referente a las responsabilidades contraidas por el señor, o, incluso a su compromiso de respeto a los derechos, usos y costumbres del lugar, como se recoge en el documento de toma de posesión de Hellín, en mayo de 1468 , cuando el procurador Diego de Soto, actuando en nombre del señor, "fizo juramento en forma devida de derecho en anima del dicho señor don Diego López Pacheco, nuestro señor, de guardar e que guardará todos los previllejos, e franquizas, e libertades, e sentençias, e hordenanças, e usos, e costunbres, que esta dicha villa tyene e ha, et que el dicho señor don Diego López Pacheco, nuestro señor, non yrá ni los quebrantará nin derogará, él nin otro por él, en ningún tienpo nin por alguna manera ni causa ni razón que sea" ${ }^{50}$. De alguna forma, los derechos vasalláticos se hacían oir, en algunas ocasiones.

\section{La gestualidad vasallática}

Oficiales, hombres buenos, y vecinos, en el caso de señoríos de nueva constitución, recibían la noticia acompañada de la orden de la instancia de poder concedente, que comunicaba a los vasallos los contenidos expresos de su dependencia, y las actitudes de sumisión a adoptar: "vos exiban e fagan e guarden la reverençia e obediençia e sujeçión e fidelidad e pleito e omenaje e juramento e todas las otras cosas....e consientan usar a vos...de la dicha justiçia e jurisdiçión.. e vos recudan e fagan recudir con todas las rentas e pechos e derechos e penas e caloñas e otras qualesquier cosas", todo esto acompañado además de la advertencia dirigida a evitar cualquier situación de resistencia - "que vos non pongan nin consyentan poner en ello nin en parte de ello, enbargo nin contrario alguno" 51 . Desde ese mismo momento, se constituía el protagonismo de los vasallos, en la recíproca acción de entrega del señorío.

\footnotetext{
${ }^{50}$ Archivo Histórico Nacional, Frías, leg. $666, \mathrm{n}^{\circ} 2$. En términos semejantes se expresa en el documento del condado de Benavente, cuando Juan de Pimentel "dixo quel estava presto de les prometer e guardar e mantener sus privilejos e sus libertades et sus buenos usos et buenas costunbres, segund que mejor les avían oydo guardados e mantenidos": Archivo Histórico Nacional, Nobleza, Osuna, leg. 516-3".

${ }^{51}$ Archivo Histórico Nacional, Nobleza, Frías, caja 4, n⿳ 16, concesión de Moya a Juan Pacheco.
} 
La actitud de respuesta comenzaba con las muestras de profundo acatamiento, a través de los expresivos gestos habituales, según leemos, por ejemplo, en el traspaso de señoríos realizado por don Juan Pacheco a su hijo: "tomaron la dicha carta del dicho señor maestre en sus manos, e pusiéronla sobre sy, cada uno en sus cabeças, e dixeron que por sy, e en nonbre de todo el dicho conçejo e ofiçiales, e de los que oy non eran, e de todos los otros que oy eran, presentes e absentes, vezinos e moradores e la dicha villa, que obedeçían e obedeçieron la dicha carta de su señor....e que son prestos de le dar la obediençia e fidelidad, commo a su señor" ${ }^{52}$. En algunos casos se insiste en los documentos en que la expresión verbal del acatamiento se producía de forma conjunta, "todos a una boz" 53 .

A continuación, dispuesto también el ánimo vasallático, que los documentos reflejan con expresiones alusivas _ "de sus agradables voluntades, reçibieron e tomavan e tomaron por su señor"- se iniciaban los gestos correspondientes a la representación de su compromiso, que se extendía a la entrega de la posesión del lugar, el consentimiento del uso de las facultades gubernátivas y jurisdiccionales, así como la promesa de realizar los pagos correspondientes, y de obedecer los mandatos señoriales, como, por ejemplo, la llamada militar, - "et para yr a sus llamamientos por sus personas et con sus armas" ${ }^{54}$ - . Las actitudes vasalláticas se planteaban desde la perspectiva de la reciprocidad; como si del reverso de la moneda se tratara, cada uno de los gestos señoriales apuntados llevaba aparejado su complementario vasallático. Así sucede, por ejemplo, con la obligada entrega al señor de los símbolos de los oficios, o la salida por la fuerza de los espacios señoriales, así como los correspondientes recepción de objetos, y entrada en los lugares indicados por orden señorial. Son de destacar los gestos, igualmente contrapuestos, de levantarse mientras el señor se sentaba, y la práctica de la habitual "reverençia" - probablemente movimientos de

\footnotetext{
${ }^{52}$ Toma de posesión de Sax, Archivo Histórico Nacional, Nobleza, Frías, leg. 666, n 4, y de Hellín, traspasada igualmente por Pacheco a su hijo: ibidem, leg. $666, \mathrm{n}^{\circ} 2$. Más allá de esta cuestión, el hecho se presta a una interpretación desde otras perspectivas, relacionadas, por un lado, con las motivaciones concretas de dicha renuncia en el contexto socio-político, y, por otro, con la preeminencia alcanzada por el marqués de Villena, que presentaba en el documento unos contenidos y un lenguaje con claras claves de mímesis respecto del poder regio.

${ }^{53} \mathrm{Ver}$, por ejemplo, el documento mencionado supra, correspondiente a Hellín: "E dixeron todos a una boz que obedesçían por su señor natural al dicho señor, don Diego López Pacheco".

${ }^{54}$ Ambas expresiones corresponden a un documento del Archivo Histórico Nacional, Nobleza, Osuna, leg. 516, $\mathrm{n}^{\circ} 3(11)$, que se refiere a uno de los señoríos del linaje Pimentel.
} 
genuflexión recta-, dirigidos al señor, y acompañados de la osculatio manuum, en signo de fuerte dependencia, como se lee en el caso de Torrico: "El dicho señor se posó en un poyo, e estando posado levantáronse los omes buenos susodichos, vezinos e moradores en el dicho lugar, cada uno por sy, uno a uno, e venieron donde el dicho señor Ferrand Álvarez estava, faziendo la reverençia, e todos le besaron la mano, e dixeron que le resçibían e resçibieron por su señor, con aquella reverençia que podían e devían"55. La documentación insiste en los detalles del simbolismo corporal, al hacer referencia a que se trataba de la "mano derecha" señorial, y a que el beso lo realizaban "con sus bocas" 56 .

Acompañaban a todo esto los juramentos, que, en sus distintas fórmulas, se adecuaban a las diferencias de status y posición en el conjunto de habitantes de los señoríos. Así, por un lado, se observa la generalizada práctica del juramento religioso, por parte de los vecinos integrados en el sector popular, mientras, por otro lado se encuentran los juramentos correspondientes a los oficiales concejiles investidos por el señor, como se lee en el caso de Montemayor - "con toda umildad e reverençia que fizieron, juraron cada uno dellos en devida forma, por el nonbre de Dios e de Santa María, e por la señal de la Cruz,.... e por las palabras de los Santos Evangelios....que bien e leal e derechamente usarán de los dichos ofiçios... a todo su leal poder...e de non fazer en ello fraude nin elusyón alguno"-, donde, a continuación se incluye una curiosa referencia explícita a la multiplicidad de instancias de poder, y a los correspondientes compromisos contraidos por los oficiales de concejos de señorío - "guardando, commo juraron de guardar todavía serviçio del rey nuestro señor, e del dicho Martín Alfón, su señor, e el pro e bien común de la dicha villa e de la república e juridiçión e términos dellas, todo bien e conplidamente" ${ }^{\text {57 }}$. Finalmente, no faltan los pleito-homenajes prestados por quienes disfrutaban de la condición de hidalguía, en especial, por parte de los alcaides de las fortalezas, quienes, por otra parte, sabemos que alcanzaban una posición de reconocimiento en los lugares de señorío, como agentes señoriales de carácter especial, a los

\footnotetext{
${ }^{55}$ Archivo Histórico Nacional, Nobleza,Frías, leg. 1326, n ${ }^{\circ} 11$.

${ }^{56}$ Así se contiene en el documento de Cañete de las Torres, donde se alude también, de forma global, a los "omenajes e juramento e fidelidad que en tal caso eran tenudos, e todas las otras insinas e onrras e señal de señorío que de derecho se devía faser": $M^{\mathrm{a}}$ Concepción Quintanilla Raso, Cañete de las Torres, ob. cit., pp. 103-104.

${ }^{57}$ Archivo Histórico Nacional, Nobleza, Frías, leg. 1340, no 5.
} 
que, en cierto modo, estaban supeditados los vasallos de la villa, según se reconoce explícitamente en algunos casos, como el del señorío de Montemayor: "e que le darán todo su favor e ayuda al alcayde del castillo desta dicha villa para lo guardar e anparar e defender" 58 .

Las responsabilidades contraidas en virtud de todo lo anterior, estaban en relación con la debida obediencia, sujeción y fidelidad. En el caso de los castillos, se añadía el compromiso de la defensa del edificio, y, por extensión, de la villa, y la promesa de acoger al señor en los términos en que lo requiriese: "el dicho Álvaro de Juera se costituyó por su alcayde del dicho Martín Alfonso de Montemayor, e faziendo commo fizo al dicho....pleito e omenaje, e juró por Dios e por Santa María e por los Santos Evangelios e por esta señal de cruz en que puso su mano derecha, de tener e guardar el dicho castillo e fortaleza para el dicho... e en nombre del dicho...., e de resçebir al dicho...ayrado o pagado, en el dicho castillo e fortaleza, de noche e de día, con pocos o con muchos, commo señor de la dicha villa e castillo" 59 . De la firmeza de los compromisos dan idea las fórmulas ceremoniales, en las que se obligaban, literalmente, "por si e por sus bienes mobles et rayzes, avidos e por aver... a conplir e mantener todo lo sobredicho, bien e leal e verdaderamente, commo sus vasallos leales en todo et por todo", y se aludía a las penas correspondientes en caso de quebrantamiento de juramentos, tanto en el caso de los alcaides de las fortalezas señoriales, firmemente sujetos en razón del pleito-homenaje, como de los vasallos de la villa:"que incurramos e ayamos, e incurran e cayan, en aquellas penas que son fechas e establesçidas por leys e fueros e ordenamien-

\footnotetext{
${ }^{58}$ Ibidem, Frías, leg. 1340, n⿳ 5 . Uno de los ejemplos más destacados de la destacada posición del alcaide lo encontramos en el documento referente a la toma de posesión del castillo, y, por extensión, de la villa de Montilla: $\mathbf{M}^{\mathrm{a}}$ Concepción QUINTANILla Raso, Contenidos, simbolos, ob. cit.

${ }^{59} \mathrm{Ibídem}$, Frías, leg. 1340, $\mathrm{n}^{0}$ 5. Mucho más detallado resulta el compromiso del alcaide de Montilla: Archivo Ducal de Medinaceli, Sección Histórica, leg. 281 (caja 39), n" 40: "El qual dicho alcayde.....quél terná e guardará el dicho castillo e fortaleza et villa por el dicho don Alfonso, e para él, e que pornía e porná en el dicho castillo e villa buena guarda, leal e verdadera, et que non acojeríanin acojerá en el dicho castillo e villa a persona alguna poderosa, salvo al rey nuestro señor, e al dicho don Alfonso, et a la señora doña Elvira, madre e tutriz del dicho don Alfonso, e en su nombre dél, a los quales señor rey et don Alfonso e doña Elvira que acojería e acojerá yrados o pagados, de día o de noche, con pocos o con muchos, et non a otra persona alguna, et que cada e quando el dicho don Alfonso o la dicha doña Elvira su madre e su tutriz, en su nombre, le mandaran desenbargar e darles e entregarles el dicho castillo e torre e fortaleza e villa, que gelo dará et entregará libremente, e lo alto e baxo del dicho castillo e de la dicha villa": Ver Apéndice documental de la obra "Orígenes de la Monarquía Hispánica”, ob. cit., doc. 16, pp. 429-430.
} 
tos en tal caso, e asy commo si fiziésemos la mayor traiçión del mundo", o bien "sopena de caer, por el fecho mesmo, en caso de perjuros e ynfames, e en caso de menos valer, e de perder los bienes e los cuerpos e quanto han" ${ }^{\prime 60}$. La fuerza y gravedad de los juramentos promisorios era patente.

A veces, la sujeción vasallática alcanzaba una dimensión más amplia, manifiesta en típicas expresiones cargadas de sentido feudal, relacionadas con la defensa de la persona del señor, y los aspectos complementarios de búsqueda de su beneficio, y evitación de su perjuicio, como se reconoce abiertamente en algunos casos: "e que guardarán su persona e su onrra, e que non serán en consejo nin en obra por sy nin por otro, de que pueda recresçer desonrra nin mal nin dapno...e quando quier que algunos trabajen de fazer el contrario, que punarán de fazer quanto podieren, que non sea asy, pero sy non lo podieren desviar, que lo aperçibirán de ello lo más ayna que se pueda, e que serán buenos e leales vasallos, e que farán e guardarán todas aquellas cosas que buenos e leales vasallos deven e son tenudos de guardar a su señor, e que sienpre guardarán sus secretos" ${ }^{61}$.

\section{CONCLUSIÓN: IMÁGENES Y MENSAJES}

Las tomas de posesión de señoríos por parte de la nobleza pueden definirse, en cierta manera, y a partir de una perspectiva comparada con el poder regio, como ceremonias de acceso al poder, o, en todo caso, como una mezcla de este tipo de ceremonia, y otra calificada de recepción, a las que, en cierto modo, se asemejaban, aunque las nobiliarias estaban privadas

\footnotetext{
${ }^{60}$ Sobre la gravedad del juramento específico de los alcaides, ver la expresión textual del documento sobre la fortaleza de Montilla, cit. supra: "so las penas escriptas en derecho en tal caso, e sopena de trayçión e de las otras penas en que caen e yncurren aquellos que traen castillo o matan a su señor". En cuanto a los párrafos del texto que corresponden a los vecinos de señoríos, proceden, respectivamente del: Archivo Histórico Nacional, Nobleza, Osuna, leg. $516, n^{\prime \prime} 3^{\prime \prime}$, sobre Benavente; Osuna, leg. 3334, n" 9, sobre Saldaña; e ibídem, Frias, leg. $1340, \mathrm{n}^{\circ} 5$, referente a los vasallos de Montemayor.

${ }^{\circ A s i ́ ~ l o ~ r e c o n o c i ́ a n ~ l o s ~ v a s a l l o s ~ d e ~ S a l d a n ̃ a . ~ e n ~ l a ~ t o m a ~ d e ~ p o s e s i o ́ n ~ d e l ~ s e n ̃ o r i o ~ p o r ~ d o n ~}$ Diego Gómez de Sandoval, en 1418:Archivo Histórico Nacional. Nobleza, Osuna. leg. 3334,
n"9.
} 
del alto grado de espectacularidad característico de los actos de coronación, $y$ de las entradas reales, respectivamente ${ }^{62}$.

Las ceremonias analizadas derivaban de forma natural hacia el imaginario de la nobleza, entendiendo por imagen, la representación viva y eficaz de una cosa por medio del lenguaje (visual, verbal -oral, escrito, o mixto-, y gestual). Las imágenes obtenidas se convertían, desde su perspectiva simbólica, en reflejo o expresión de una realidad, pero al mismo tiempo podían adoptar el sentido de técnicas de manipulación, manejadas por la instancia señorial, y orientadas hacia la sublimación de su poder.

Eran, además, instrumentos de proyección de mensajes. Rituales y símbolos, con su sentido legitimador y propagandístico, tenían una intencionalidad, y provocaban un efecto. Por un lado, encerraban un mensaje señorial, claro y directo, con contenidos dirigido a unos receptores, que se veían obligados a ofrecer reacciones y respuestas, en definitiva, un contramensaje, que se inscribía en actitudes de pasiva conformidad, o, según los casos, podía derivar hacia la la desviación, la resistencia, o, incluso, el conflicto. El mensaje señorial que se desprendía de la propaganda ceremonial se articulaba en torno a la polaridad entre la auctoritas-potestas, y la persuasio. Por un lado, se orientaba hacia la expresión de un poder legitimado, que se traducía en el mandato y se fundamentaba en la imagen que se desprendía de las ceremonias, en las que el titular del señorío aparecía como señor "legítimo y verdadero", o, incluso, como "señor natural”, ${ }^{63}$, En este contexto, el mensaje vasallático respondía a una pauta de reciprocidad, caracterizada por la obediencia manifiesta de forma amplia, y

\footnotetext{
${ }^{62}$ Un estudio muy completo referido a la monarquía castellana bajomedieval, y que permite establecer esos intentos de análisis comparativo, en la monografía de José Manuel NiETo SORIA. Ceremonias de la realeza. Propaganda y legitimación en la Castilla Trastaimara, Madrid, 1993. en especial capítulo I, y pp. 122, 130-133. En el ámbito señorial existía, no obstante. otra situación. que podía alcanzar la perspectiva de ceremonia, con mayor o menor solemnidad. y para la que no existen muchos testimonios referentes al período bajomedieval: son las visitas señoriales a las villas, gestos de significado amplio y diverso, que iba desde la exhibición propagandística de la figura nobiliaria, hasta la manifestación de actitudes claramente paternalistas, recomendadas por algunos tratadistas de la épocia, que aludian a la conveniencia de que los señores visitaran sus villas para así "alegrarlas con sus presencias corporales”, como el teólogo agustino Juan de Alarcón: $\mathrm{M}^{\mathrm{a}}$ del Carmen PASTOR CUEvAS, Estudio y edición del "Libro del regimiento de los señores" de Juan de Alarcón, Tesis doctoral, Universidad Complutense, Madrid, 1993. En estos momentos, preparo un trabajo acerca del significado de estos actos. de los que aún se sabe muy poco.

${ }^{6.3}$ La primera expresión procede del documento referido a Saldaña, del Archivo Histórico Nacional, Nobleza. Osuna, leg. 3334. $n^{\circ}$ 9; la otra corresponde, entre otros, a los documentos sobre Hellín, ibidem, Frias, leg. 666, n"2, e ibídem. Osuna, leg. 516, n" 3 (11).
} 
a veces con perfiles de voluntariedad y espontaneidad, señalados antes en los mismos documentos, en los que, a menudo, se subrayaba que la toma de posesión se había realizado "pacíficamente", o, "pacíficamente, sin contradiçión de persona alguna", o de forma más detallada, "pacíficamente, syn reclamaçión nin contradiçión alguna de alguna nin algunas personas que gelo contrallasen nin embargasen" ${ }^{64}$.

En el ámbito de la manipulación, se destacan claras tácticas paternalistas, e integradoras, para configurar un mensaje ideológico, en el que las actitudes de magnanimidad a veces apuntadas en esas ceremonias, alcanzaban un sentido determinante. Desde esta óptica hay que tener en cuenta el ejercicio de la gracia señorial ${ }^{65}$, o los actos de clemencia, en relación con la administración de justicia - por ejemplo el perdón generoso de algún condenado-, que estaban encaminadas a lograr la más amplia y efectiva aceptación vasallática ${ }^{66}$.

No obstante, pese a esta aparente concordancia de posturas, los testimonios de toma de posesión incluían, a veces, mensajes tácitos orientados a matizar algunos contenidos de los anteriormente comentados. Así sucedía, por ejemplo, cuando el señor prometía expresamente respetar los usos y costumbres de las villas y sus habitantes, con fórmulas que han sido indicadas antes, lo que demuestra una actitud suficientemente coherente y organizada de los habitantes del señorío, en defensa de sus intereses. En algunos documentos, los vasallos hacían constar su múltiple dependencia respecto de las distintas instancias de poder - manifiesta en la necesidad de atender al servicio del rey, no sólo al del señor-, y, lo que es más importante aún, ponían de relieve su compromiso de respetar - según se ha señalado antes-, "el pro e bien común de la dicha villa", compromiso del que, naturalmente, de forma indirecta, se desprendía una advertencia a la

\footnotetext{
${ }^{64}$ Respectivamente, tomas de posesión de las feligresías de la tierra de Aguiar. de Torrico, y de Montemayor: Archivo Histórico Nacional, Nobleza, Osuna, leg. 516, $\mathrm{n}^{\circ} 3$ (11). Frías, leg. 1326, n" 11, y Frías, leg. 1340, n" 4.

${ }^{65}$ Más allá de la pura fórmula - "Yo don Juan Pacheco...a los conçejos y ofiçiales de la nuestra çibdad de Chinchilla,,, y de todas nuestras villas y lugares del nuestro marquesado de Villena, salud e graçia": Archivo Histórico Nacional, Nobleza, Frías, leg. 666, n" 4-, el tema de la "gracia señorial" alcanzó un notable significado en el ejercicio de un poder, que. en muchos aspectos, se planteaba sobre la actitud mimética respecto del poder real.

${ }^{66}$ Interesantes consideraciones al respecto, en el artículo de Ignacio ATIENZA HERNÁNDEZ. Consenso,solidaridad vertical e integración "versus" violencia en los señorios castellanos del siglo XVIII y la crisis del Antiguo Régimen, en "Señorío y Feudalismo en la Península Ibérica”. E. Sarasa, y E. Serrano, edits., Zaragoza, 1993, II, pp. 275-318.
} 
autoridad señorial, para evitar que atentara contra los derechos de la población. La insistencia con que en algunos documentos se alude a la normalidad de la entrega de la villa por los vasallos, mediante expresiones formularias añadidas a instancias del señor, daban a entender el recelo ante una posible reacción de resistencia, por lo que se insistía en la necesidad de, literalemente, "le dar e entregar la dicha villa.....sin dilaçión nin escusa alguna" ${ }^{67}$.

Las tomas de posesión de los señoríos nobiliarios en la Castilla bajomedieval ponen de relieve sensibilidades e ideologías; con su sentido ritual, y con el simbolismo de su lenguaje múltiple, contenían, tácitamente, algunos reflejos difusos de la imagen de "buen señor" - comprometido a no abusar de su posición-, y a su vez, otra muy poco definida de "vasallo consciente de sus derechos". Pero, sobre todo, lo que ofrecían de forma expresa y rotunda, desde la perspectiva de relación entre - literalmente- el "señor natural" y sus "vasallos y súbditos naturales" eran las imágenes de "señor poderoso", y de "buen vasallo", todo ello mediante fórmulas que combinaban, pedagógicamente, la fuerza y la persuasión, en búsqueda de un objetivo de estabilidad interna, convertido en mensaje ideológico globalizador, que, sin embargo, no siempre alcanzó el mismo nivel de eficacia ${ }^{68}$.

\section{RÉSUMÉ}

Cet article a pour objet l'analyse du système de relations dans les seigneuries par l'étude du rituel de la mise en scène dans les prises de possession. La représentation ceremonielle et symbolique de l'ordre seigneurial, evec ses aspects formels - des mots, des objets. des gestes- nous permet d'observer, parfois, des images diffuses des engagements seigneuriaux et des droits des vassaux; mais, pardessus tout, elle servait à donner un message bien évident de pouvoir seigneurial et de soumission des vassaux, les deux éléments essentiels du système.

\footnotetext{
${ }^{67}$ Entre otros ejemplos, Archivo Histórico Nacional, Nobleza, Osuna, leg. 1334, n"9, sobre el señorío de Saldaña.

${ }^{68}$ Expresiones tomadas del documento del Archivo Histórico Nacional. Nobleza. Osuna, leg. 516, $\mathrm{n}^{\circ} 3^{11}$. No es éste el momento para adentrarse en la panorámica de la resistencia antiseñorial, tema de profundo y complejo contenido. Entre la amplia bibliografía relacionada con estas cuestiones, un reciente artículo pone de relieve la capacidad de organización de los vasallos señoriales en la dinámica de relación entre las reivindaciones señoriales, y la resistencia vasallática: Carlos LALIENA CORBERA, Coerción y consenso: un levantamiento antiseñorial aragonés, Maella, 1436-1444, en "Scripta. Estudios en Homenaje a Élida García García". Oviedo, 1998, pp. 297-319.
} 


\section{SUMMARY}

The study of the ritualized staging during the inaugurations is what we have taken into account in order to analyze the system of relationships within the seigniories. Thanks to the ceremonial and symbolic representation of the seigniorial class system, with its formal aspects - words, objects, gestures-. we can observe diffuse images of the seigniorial compromises and of the rights of the vassals. But the essential objective of that representation was to show the seigniorial power and feudatory submission principles in which the feudal system is based. 